\title{
Law and Argument for a Culturally Diverse World: How not to Communicate
}

Direito e argumento por um mundo culturalmente diversificado: como não comunicar

Droit et argument pour un monde culturellement diversifié: comment ne pas communiquer

\section{Richard Mohr}

\section{(2) OpenEdition}

\section{Journals}

Electronic version

URL: https://journals.openedition.org/rccs/6584

DOI: $10.4000 /$ rccs.6584

ISSN: 2182-7435

\section{Publisher}

Centro de Estudos Sociais da Universidade de Coimbra

Printed version

Date of publication: 1 May 2017

Number of pages: $73-98$

ISSN: 0254-1106

\section{Electronic reference}

Richard Mohr, "Law and Argument for a Culturally Diverse World: How not to Communicate", Revista Crítica de Ciências Sociais [Online], 112 | 2017, Online since 15 May 2017, connection on 21 September 2021. URL: http://journals.openedition.org/rccs/6584 ; DOl: https://doi.org/10.4000/rccs.6584 


\section{RICHARD MOHR}

\section{Law and Argument for a Culturally Diverse World: How not to Communicate}

This paper reviews the role of discourse in law and public life and identifies threats to the polity from malicious forms of communication. In addition to its role in legal argument, communication is fundamental to public debate in the formation of laws and policies, and it constitutes the social and political fabric through the use of forms of address and recognition of others. This argument builds on aspects of discourse theory and feminist and other critiques of it that suggest that it applies to a narrow community of discourse, and so excludes other cultures. It takes a broad view of participants in public debate, which necessarily crosses national and cultural borders. Responsible communication demands that we argue in good faith, truthfully and coherently, and that we recognize our partners in discussion, both for who they are and for their place in a shared community. The paper argues that public discourse has sunk to dangerous levels in the present century, citing examples of bad faith, provocation and insult from Australian prime ministers $(2002,2015)$ and presidential candidates in France (2005) and the United States (2016). It concludes that lying, incoherence, self-contradiction, insult and injury fall outside the bounds of public discourse. Rapid communicative intervention is needed to identify each of these malicious forms of communication as a betrayal of the civic public, before it provokes the next vicious response.

Keywords: cultural diversity; discourse theory; epistemology; law; malicious communication; rhetoric.

\section{Part 1 - Law and Communication}

\subsection{Public Discourse and Law}

Discourse and argumentation are fundamental to law. This has been increasingly well-understood with the declining dominance of positivism, which emphasized rules over argument and the state as the single source of law. This article explores the implications of this renewed focus on discourse and law in contemporary polities. Earlier conceptions of the polity, from Aristotle to Habermas, assumed a degree of homogeneity among the discursive participants. Clearly the gender and class of the political actors have become more various over the centuries. However, as long as a polity 
is defined by linguistic and national boundaries there will be constraints on the inclusiveness of discourse. Major cultural differences become salient when discourse is conducted internationally, or among diverse cultural groups within a national community. Because of migration, global trade and telecommunications (the Internet, news and television networks), these circumstances now prevail widely within and across nations. This diversity of discursive participants is the first impetus for this inquiry into the criteria for effective communication.

The second impetus is the disconnect currently experienced in public discourse between, on the one hand, the guidance and exhortation to communicative competence and ethics, and on the other hand the deplorable state of much current political and legal debate around matters of legislation, election, argument and ajudication. This inquiry is driven by the need for relevance in an environment of mistrust, untruth and xenophobia. These unfortunate communicative practices are not new, but their contemporary prevalence has caused this author to rethink the priorities in communicative ethics. Earlier work parsing and analyzing the niceties of civil and inclusive debate seems increasingly irrelevant. This paper aims to identify the vices as well as the virtues of communication in a culturally diverse world.

"Culture" is used here in a broad sense to indicate a complex of beliefs, practices, tastes and ways of communicating that inhere in groups and may vary between them. Following Appiah (2016), the gulf between Arnold's "high" culture and Tylor's "primitive" culture is seen as confused and ill-conceived. On the other hand, Bourdieu's analysis of culture penetrates the subtle social differences within as well as between societies. ${ }^{1}$ Having adopted a broad definition of culture, my discussions of "intercultural" or "cross-cultural" communication or discourse apply equally to relations between different groups with their own ways of thinking and communicating. Those groups could be based on class (even within quite small populations), on language (whether dialect or lingua franca), on religion (from sects to world religions), and so on. In each case, scale is irrelevant: what is important is the need to communicate between cultural groups, whether in the next street or around the world. The nation-state has long been taken to be the natural level on which public discourse takes place, based on assumptions of ethnic homogeneity, common language and exclusive legal sovereignty. Those cultural and jurisprudential assumptions will be questioned in the following pages.

\footnotetext{
${ }^{1}$ Bourdieu (2010: 61, 69) critiques the ideological "naturalization" of taste as a product of class struggle that denies its social and cultural origin: "Every material inheritance is, strictly speaking, also a cultural inheritance".
} 
The aim of this inquiry is to explore some of the neglected aspects of discourse in the public sphere, particularly as it is relevant to legal debate. This is taken to include debates in legislatures, in electoral contests, and in arguments within and around litigation and adjudication. While discourse theory and communicative ethics have effectively addressed the criteria for good communicative practices in homogeneous polities, this paper asks broader questions. The particular focus is on heterogeneous communities, both within and across national borders. And rather than emphasizing ideal communicative practices, the focus turns to unethical, malicious and vicious ways of communicating, in order to identify forms of debate that are unacceptable in diverse communities. A clearer understanding of the limits of public discourse will lead to some conclusions as to how to respond to malicious forms of communication.

The first part of the paper shows how discourse, as argumentation and as communicative action, enters into key aspects of the legal process. Each of the following approaches to law's relationship to discourse and language has been important in illuminating the links between law and the humanities. If not always specifically referring to law per se or narrowly defined, they have helped to show how law is argued, constituted or embedded in the polity.

The second part considers the virtues required for good communication. This work assumes, as a baseline, Habermas's (1990) long-running project of specifying the conditions for communicative action and the debates it has stimulated. That work is expanded with a particular emphasis on communication among diverse participants. So, as well as the Kantian and Habermasian virtues of arguing in good faith and adhering to truthfulness, coherence and non-contradiction, we add recognition of difference within discursive communities. Recognition must have cognitive, constative, constructive and performative dimensions.

The third part of the article, spurred by concern over the increasingly vicious tone of public discourse in western democracies, seeks to understand and diagnose communicative vices. ${ }^{2}$ The structure of this argument takes the comparatively well-known virtues and considers how they are inverted into vices: bad faith (lying, incoherence and self-contradiction) and misrecognition (insult, offense, blasphemy and curse).

In line with its focus on public and intercultural communication, the article concludes by identifying the most pernicious forms of miscommunication

\footnotetext{
${ }^{2}$ Here I take advantage of the semantic relationship between the noun "vice", as the opposite of virtue, and its adjectival form "vicious", which also indicates excessive violence and malevolence. Both senses are fully intended.
} 
in diverse polities and proposing responses. The argument goes beyond a Habermasian advocacy of communicative virtues in its forensic and diagnostic analysis of communicative vices, to denounce them as betrayals of humanity.

\subsection{Argumentation in Law}

One could draw on numerous and diverse sources to try to define the nature of law. However, the purpose of this article is not to attempt to explain law beginning from first principles, but rather to consider the importance of discourse and argumentation in public and legal communication. For this purpose, I adopt Santos's comprehensive, if not definitive, view of law as

a body of regularized procedures and normative standards, considered justiciable in a given group, which contribute to the creation and prevention of disputes, as well as to their settlement through an argumentative discourse coupled with the threat of force. (1995: 112)

Discourse and argumentation are central to law, whether at a national or local level. This definition emphasizes disputes, the locus for the resolution of which may be a formal law court or some informal forum. The emphasis in the passage quoted on the standards specific to a given group opens the discussion to a plurality of legal regimes which can co-exist and interpenetrate. Santos and other legal pluralists have focused on informal and alternative dispute resolution, which can operate on a number of levels, from small local communities to nation-states and international arbitration.

The role of discourse and communication in law is expanded by considering the relevance of argumentation theory to formal adjudication, and consequently to discourse more broadly. Coherence is widely held to be a central value in judicial deliberation. Kennedy addresses the problem of the missing link between strict legal deduction and the (just) decision by looking at a wide range of proposed solutions. For MacCormick, Dworkin and the Franco-German "free law" (or "free research") movement, coherence is a key component of that link (Kennedy, 1997:31-38). Yet coherence is a two-edged sword in judicial interpretation. On one reading, coherence within the law leads to a closed system which is sealed off from broader public discourse (Teubner, 1989: 752). Lukács even saw demands for internal coherence as leading to the fetishization of law (Varga, 1985: 114, 140). However, it is possible to posit coherence as a way out of this cul-de-sac. Gény's solution to the inability of strict law to provide the means to decide 
every case was to propose the judge's power to look outside the law, by means of "free and scientific research" (Frydman, 2011: 8).

Perelman developed this by proposing that argumentation allows a choice of actions. It is the basis of discussion and deliberation by means of which one justifies, objects, refutes and gives reasons. He saw this "logic of value judgments" as the alternative to the dilemma arising from the elimination, in the previous two decades, of the middle ground "between an irrationalism and a positivism, both alien to the idea of the reasonable so important in law" (Perelman, 1980: 108). This method of deliberating and deciding clearly applies to judicial deliberation. Once it is accepted that the role of the judge is to mediate and decide between two arguments rather than to apply a strict rule to a specific case, the field is open for a discourse analysis of the judicial process. The relevance of this approach was demonstrated in the work of the Belgian courts throughout the 1960s, when the approach of Perelman and the école de Bruxelles was

integrated [...] into judicial practice to effect profound and lasting changes in the very content of law, in the manner of deciding cases and more broadly in the role of the judge in a democratic society. (Frydman, 2011:3)

Coherence is also relevant to public discourse through epistemological considerations. On this reading, legal discourse need not be merely internally coherent but may be linked to ways of knowing in the world outside the law. Amaya (2008: 306) calls for "epistemic responsibility", according to which the judge would have to test factual claims by reference to "coherence in like circumstances". Brenner (2011) recognizes that in scientific as in judicial reasoning there are aporias of decision-making which must be overcome by appeals to values such as coherence. Adopted by feminist epistemology, coherence theory offers a radically open approach, connecting "knowledge, power and desire" in a project for a "normative theory of knowledge that can offer an epistemic account of how evaluative distinctions between competing claims should (and can) be made" (Alcoff, 1996: 2). Coherence will be considered below as an important virtue in public and judicial communication.

\subsection{Communicative Action, Legislation and the Polity}

Law is expressed in legislation as much as in judicial decision-making. Here too we can see the relevance of public discourse to electoral and parliamentary debate and to discussion in the various public forums that set legislative agendas. High profile events and moral panics are known to 
drive legislative change, for example in "law and order" campaigns and the issue of "terrorism" versus human rights. These political and legislative programs are mediated through public discourse in a range of mainstream and social media.

At a more fundamental level it has been proposed that communicative action constitutes the polity itself. Such an idea can be traced back to Aristotle's (1995) conception of the good life as based in public, political action, and Hegel's (1967) linkage of law with association, plurality and publicness (Cohen and Arato, 1992: xiv). Here we focus on some more recent developments of the theme of communicative action.

Communication is, first of all, fundamental to our humanity.

Action and speech are so closely related because the primordial and specifically human act must at the same time contain the answer to the question asked of every newcomer: 'Who are you?'. (Arendt, 1959: 158)

In such a schema, action contributes to the polity, while we enact our humanity in and for the public sphere.

In his analyses of decision-making within democratic states, Habermas has proposed that legitimacy derives from optimal communication among all participants. After initially applying it simply to the democratic processes of the public sphere (Habermas, 1990, 1991), Habermas extended his theory into law with Between Facts and Norms. His explicit intention was to save law from systems theory and to bring back intention and the relevance of rational debate to law: in short, to reinstate "the internal connection between law and the constitutional organization of the origin, acquisition and use of political power" (Habermas, 1996: 50).

\section{Part 2 - Communicative Virtues}

\subsection{Good Faith}

The first principle of ethical argumentation and public discourse is the requirement to argue in good faith: no lies, maintain coherence, and avoid self-contradiction. Each one of these requirements could be discussed and qualified at length, but here I will go into a minimum of discussion about the nature of each.

\section{Truthfulness}

To lie is to be untruthful: to say things that are false. Two points need making here: first, whether there is an intention to tell falsehoods and, second, how truth is to be defined. Of course, each of these is a broad field of inquiry. 
Intention is central to findings of guilt in criminal law, and an important subject of philosophy (Anscombe, 1963). Truth is the concern of the wide and flourishing field of epistemology. In what follows, we will deal briefly, and only to the extent necessary for the development of our argument, with intention and epistemology (or the nature of truth).

Firstly, on intention: we can say something that is untrue in good faith. That occurs when we are mistaken, when we genuinely, and with some evidence, believe something to be true which turns out not to be. If we are debating in good faith, then the very truth of a statement, and the warrants supporting our belief that it is true, can be debated openly (Toulmin, 1964). On the other hand, someone who does not know whether a statement is true or false and, furthermore, does not care, may be uttering truths and falsehoods indiscriminately. Here the speaker is so thoroughly and willfully confusing fact and fiction that it constitutes bad faith (this will be considered later, using examples of false news and political falsehoods). As is the case in criminal law, intention counts for a lot in determining whether truth or falsehood are uttered in good faith.

Next - and we pause for breath! - the nature of truth. For present purposes we can simply say that something is true if it corresponds to an external state of affairs. This requires, first of all, a measure of confidence in our sense perceptions and in the view that they can be common to, or shared with, others through processes of discourse and language. This is not to assert that there are independent external states of affairs that are more or less accurately represented internally within our mind or in discourse. The point is, rather, that we collectively collaborate in agreeing upon satisfactory versions of the states of affairs in the world. To be workable these versions must correspond to that world -i.e., not be out of step with the way the world is - and be capable of forming the basis for meaningful discourse about the world, including our shared projects, policies and laws. As McDowell (1996: 11) puts it, the world as it is provides some "friction" for our otherwise unbounded thoughts, without which our wheels would spin. So the world that is relevant to us as a topic for debate is not characterized by external, incontrovertible "facts", or "givens", in a positivist sense. It is a world that we continue to act in and on, through human aspirations and endeavours. Discourse is the means for that joint action.

By introducing discourse as a determining element of "what can be agreed to be" truth, we enable a social epistemology. That entails always being aware of the community within which discourse makes sense and statements can be accepted as meaningful, plausible or truthful. This is different from a radically relativist epistemology, because truth can and should be judged and 
agreed upon within a community. The wider that community is, the closer the truth approaches to claims of universality. Yet we are always reminded that truth lives in a social milieu. Where there are conflicting claims to truth, the social origin of facts and beliefs in ways of living and shared projects provides a further guide to judging their truth value. Subaltern perspectives can be recognized for their origins in alterity or oppression, and judged in the context of their projects for liberation or critique. This is not to say that the subaltern or "southern" inevitably inevitably trumps the metropolitan or "northern" view. Instead it offers an alternative which is to be valued as such, which can be judged for its goals as well as its origins, and which is dignified as making truth claims no less valid than those of the dominant and too often taken-for-granted canon of the north. Universality can only be earned through dialogue, not imposed by force or authority.

\section{Coherence}

This approach incorporates criteria of coherence even into discourse about the state of the world. This is not to insist on the reliability of representation per se, which is an insistence that pits correspondence against coherence as mutually exclusive theories of truth. The reliability of our perceptions of the world is not guaranteed by sense data, but by understandings of our "shared attention to the world" (McDowell, 1996:36), which Gadamer (1989:306) has called the "fusion of our horizons". Far from seeing any inconsistency between correspondence and coherence theories of knowledge, the approach taken here follows Davidson: "Coherence concerns the relativity of sentences to language, that is, holism; and correspondence concerns the relation of speech to the world, that is, realism" (apud Dostal, 2011: 174). By triangulating coherence and correspondence we may arrive at a best fit, with the world and with each other's understandings.

\section{Non-contradiction}

The third principle for discourse in good faith is that of non-contradiction. We should maintain consistency with our own utterances, as well as with the known state of the world and the accepted meanings of the terms we use. Already it can be seen, in the need to have "accepted meanings", that this apparently simple principle admits all sorts of interpretations. My consistency might be your contradiction, depending upon those meanings. So even the axiom of non-contradiction, which Arendt (1982: 37) saw as the apex not just of Kant's logic, but of his ethics, is open to hermeneutic doubt.

Some of the most fundamental disagreements can hinge on questions of contradiction among categories. I will give two examples, one from a dispute 
in political philosophy, and the other from an imagined colonial theological encounter. In an article titled, appropriately for our argument, "Unruly Categories", Young (1997) took issue with the exclusiveness of Fraser's "binary categories" of "recognition" and "redistribution". According to Young, these were not contradictory, but could be seen as complementary. Hence, a demand for recognition of cultural rights, or of rights to education, could lead to economic advancement, and hence redistribution of resources for indigenous people. Fraser (1997) stood her ground, insisting that the contradiction between recognition and redistribution was not merely conceptual, but reflected actual social movements.

The second example comes from Bruno Latour's discussion of the origins of the idea of the fetish, in encounters between Portuguese traders and the Africans of the Guinean coast. That which is feitiço, made by humans, cannot be a deity, say the Portuguese: so, which is it, divine or man-made? But Latour's imaginary Guineans refuse to choose, since they know neither the principle of non-contradiction nor the prohibition on the worship of idols (Latour, 1996: 16).

These two examples highlight the most salient difficulties in the principle of non-contradiction, embedded in the very foundations of neo-Kantian discourse theory (à la Habermas). As soon as we leave the certainties of logical formulae for the real worlds of political activism and intercultural relations, the certainty of non-contradiction looks much more shaky. What is contradictory to an eighteenth century Portuguese sailor might be reconciled in an alternative understanding of the world. And even among socialist feminists, the contradictory nature of recognition and redistribution can be debated from several angles: empirical, rational and pragmatic. In any case, debate between different positions - cultural, political, methodological - must be accommodated if public discourse is to be possible.

These concerns have been the basis of much criticism of Habermas's discourse theory. Young (1990: 106) has taken issue with Habermas's attempt to claim universal moral outcomes from rational argument. Others have drawn attention to the broader context of deliberation, which goes beyond "the rational moral self as an isolated moral geometer" (Benhabib, 1990: 358). This broader context may include the social, affective (Young, 1987: 59 ff.) and other "argumentation-external" (Cooke, 2013) contexts, including habitus, ways of life and cultural backgrounds. While these critiques may not be fatal to discourse theory as a guide to public communication, they certainly highlight the extent to which accommodation is required in complex societies and across cultures. In addition to good 
faith, by which we maintain certain minimum standards of argument and communicative competence, we need also consider an extra virtue directed to communication with others: goodwill.

\subsection{Recognition}

Recognition is a fundamental precondition to the goodwill necessary for communication across different cultures, paradigms, political positions and methodologies. To recognize the other with whom we are in conversation or debate goes beyond empathy or Verstehen to an appreciation of diversity. To know the other in a way relevant to facilitating discourse is to understand that our interlocutor's epistemological assumptions and discursive practices may be very different from our own.

A minimum requirement of recognition is as old as Aristotle's (1960) presumption that in public discourse we should aim to persuade our audience. This involves an understanding of the audience: a recognition of who they are. Such a demand takes on different dimensions in a culturally diverse society, whether it be as small as a town or as large as the world. It is easier to address our peers in a society, or a discursive reference group that shares a wide range of assumptions, values, background knowledge and communication protocols. We only need to imagine the relevant concerns of our audience and our discourse can be tailored accordingly. Recognition in that case is a simpler communicative task than is the case in cross-cultural discourse, where we need to understand that our audience might have different assumptions, even if we do not know exactly what they are. The very recognition of difference is a necessary precondition to effective communication and respectful public discourse.

Beyond persuasion, there are, however, other reasons for expecting that participants in a discussion should be recognized, and there are a variety of means by which this can be achieved. These include the following dimensions:

- cognitive: knowing who their partners in debate are;

- constative: being capable of accurately describing them;

- constructive: in this dimension partners are mutually constituted through discourse (each address contributes to making us who we are);

- performative: the recognition that some forms of enunciation change the configuration of the social world simply by being uttered.

These forms of practice are relevant to either speaker or audience or both. In truly dialogical interactions, of course, we are always both speaker and audience, but for analytical purposes it is useful to differentiate in some cases. 
The rest of this section deals briefly with each of these forms of recognition, pairing the closely related cognitive with constative, and constructive with performative.

\section{Cognitive and Constative}

"Knowing" an audience can involve a range of cognitive facts: for instance, knowing about its histories, cultures and values. While this can be a first step towards more effective communication, grasping these facts may also be seen as a form of appropriation. Levinas (1989: 76) draws attention to the cross-over between the epistemological and the technical-ethical implications of "grasping". Gadamer (1989: 299) also warns of "the danger of 'appropriating' the other person in one's own understanding and thereby failing to recognize his or her otherness." Thus, while cognitive knowledge of the other is necessary to communication, it has its limits beyond which it becomes hubris and appropriation. The humility of recognizing one's ignorance of the true nature of the other is one essential response to this limit. Beyond that, however, is the fundamental ethical stance of recognizing the difference of the other, and respecting the very unknowability of that difference.

It is important but difficult for the speaker to find this humility and a recognition of his or her ignorance of an unfamiliar audience. It is harder still to step back and recognize that one's own benchmarks and taken-for-granted criteria are foreign to others, that they cannot automatically command universal acceptance. This was seen in relation to the criteria that discourse theory would apply to judgments of contradiction and Kantian logic.

This is not to say that there can never be criteria for aesthetic or ethical judgment that can be applied beyond the speaker and her or his own circle. It is, rather, to propose that the criteria themselves be developed through a dialogical process. Cross-cultural conversations are rich in moments when we glimpse another take on the world, gain insight into other people's histories that we did not share, and are reminded of how specific our speech and knowledge are to our own experience. Each of these glimpses opens out the possibility of further exploration, not in a rush to relativism, or to close off debate by quickly establishing a new benchmark, but as another opening for dialogue.

Communication adds to the cognitive understanding of self. To recognize the other in their diversity, and to be willing to enter into dialogue, does not diminish the identity and self-recognition of the speaker. The more we know ourselves, the better we can accept difference and communicate with others. 
Conversely, dialogue with others may be essential to an understanding of the self. In the Australian context, it is hard to know one's own place as a descendent of European settlers in a post-colonial nation based on dispossession and genocide. The moments of interracial dialogue, when one hears the alternative perspectives of indigenous Australians, can be surprising as well as illuminating of our own world. These are often not the well-known facts of injustice and disadvantage that have been addressed so thoroughly in inquiries into Aboriginal deaths in custody and stolen generations of children (though not in government responses). They are instead the life experiences and the epistemological habitus of people living in Aboriginal cultures (who also live in white culture). Dialogue as a path to recognition by which the interlocutors constitute each other is our next topic.

\section{Constructive and performative}

In relation to discourse, "recognition" is used in two senses. The first is the cognitive sense discussed above, by which we have a "true knowledge of [...] a person or group's identity or situation". The second is the "constructive" sense, as when a speaker is authorized by being "recognized" by the chair of a meeting (Markell apud Feldman, 2008: 230). So now we turn to the various ways in which speakers are "recognized" in the sense that they are communicatively constituted by being constructed by an authoritative other, or in confirming their own identity by performing a speech act.

Common law courts use particularly revealing language to indicate whether an interlocutor is recognized by the court. A party must have "standing" if they are to participate in a legal action. Legal counsel who is not authorized to appear in a matter cannot be "seen", as when the judge disqualifies a barrister who is not dressed or robed appropriately. One must stand before a court, and be seen by the judge in order to be recognized as a participant in the proceedings.

Recognition as a speaker is basic to all public life. We saw above, in section 1.3., that Arendt (1959: 158) regarded action and speech as the interlinked foundations of our humanity, through the "primordial and specifically human act" of identifying ourselves in public discourse. Revelation of the speaker's identity is essential to the political action by which we express our humanity, by which we are buman. This active participation in human affairs is only possible through the full public presence of the speaker, without which "action loses its specific character". Arendt identifies the exceptions to this rule of publicity as the criminal (who hides) and the "doer of good deeds" (who must remain anonymous): these are by definition roles and agents excluded from the public sphere of political life (ibidem: 160). 
The political agent or "public man" of Arendt's Aristotelian model seems most at home in the ancient Greek agora (as in the gender Arendt gives him). Yet contemporary public institutions have their own protocols for revealing and constituting a wider range of performative public agents: speakers are "recognized", parties "have standing", advocates are "seen" and witnesses are sworn. By swearing an oath, a person's subsequent speech acquires public status of a specifically legal nature: their identity is guaranteed and lies are punishable as perjury.

\section{Part 3 - Communicative Vices}

In this section, we analyze the problems and pitfalls of public discourse by identifying how communication can be abused. In order to identify bad communicative practices, which may be designed to deceive, confuse, insult or injure, we will proceed by inverting the communicative virtues discussed in the previous section. Having identified the virtues that lead to good communication, we use this method to identify communicative vices: good faith becomes bad faith; recognition becomes misrecognition, and so on for each of their components. The implications of each of these categories are considered in relation to contemporary public life. Discussion of communicative virtues, which is well known from the literature on communicative ethics and discourse theory, serves as counsel to all participants in how best to behave. By identifying communicative vices, on the other hand, we can venture a diagnosis and prognosis for the present poor state of public discourse. As prognosis it may serve as a warning, a caution against further deterioration. As diagnosis it is hoped that, by unveiling some of the conditions of bad communication, a number of interventions may suggest themselves.

\subsection{Bad Faith}

Lying

To lie means to make a statement that is not true, in that it does not correspond to any particular facts in the world. How important is intention to this definition? There can be degrees of lying. We may exaggerate, speculate (without full disclosure that this is what we are doing) or report on rumours or unreliable material, without taking care to ensure they are true. The difficulty of reliance on source material increases with the number of sources: this is a well-known problem with Internet and social media communication.

The problem has been illustrated in Facebook's trending news feed. In May 2016 it was revealed that this source was not entirely generated automatically from algorithms, but was mediated or curated by humans (Thielman, 2016a). This led to accusations of bias: while an algorithm could 
be relied upon to simply report the most popular news stories, humans might have ulterior motives, that is to say, intentions. Three months later Facebook fired the staff who edited the trending news. Bizarre, offensive and inaccurate reports immediately headed the trending news (Thielman, 2016b). Having done away with any checks on reliable news sources, Facebook, "now the biggest news distributor on the planet" (Thielman, 2016a), had no means of checking whether an item "represents a realworld event".

Can an algorithm lie? In the absence of intention, all that can be claimed is that it is totally indifferent to truth; this is the fundamental and pervasive problem of Internet communication. Where humans show a similar indifference to the sources and reliability of the news or "facts" they communicate, clearly there is a recklessness that destroys the truth value of anything they communicate. This may be seen in the case of climate change denial or conspiracy theories, which report rumour and fantasy to refute science and well known facts. Such recklessness, familiar also from the tweets of Donald Trump, cannot be distinguished from lying. Without trust in the source of the information, be it from Facebook or Trump, the content of the communication is so devalued as to be worthless or, worse, dangerous.

\section{Incoherence}

Coherence fits facts about the world into a framework of understanding. Where the source is incoherent or inconsistent, comprehension is diminished. As we've seen, truth requires both correspondence and coherence. Considerations of narrative coherence may shape how the facts are told, but must not distort or conceal them. Ryan (1996: 638) mischievously calls lawyers "professional liars", when all a good lawyer is doing is ensuring coherence along with correspondence. "[T]he cogency of a trial is something like the cogency of a novel or other literary work; its rhetoric and structure ought to be adapted to reinforcing the story of our commitment to conducting our affairs according to the law". This fitting of facts into a narrative structure must be distinguished from lying.

The vice of incoherence derives from failure to link relevant facts, from linking unrelated facts to paint a false or misleading picture, or from concealing known and relevant information. Incoherence is fatal to understanding and communication, since it sabotages sense-making or leaves interpretation of one's communication open to nonsense. Not only does it fail to make sense of the world and events, but it renders the rest of one's utterances incomprehensible. In this it is related to self-contradiction. 


\section{Self-contradiction}

It has been noted that non-contradiction can depend on interpretation of various terms, and that criteria for this standard may ultimately depend on a certain level of goodwill. Self-contradiction offers a stricter standard, but only if we willingly enter into the epistemological framework of our interlocutor. A statement is not self-contradictory simply because it contradicts our assumptions as listeners. So within their own framework, the Guinean carvings can be made by humans and also be deities. It is only the assumptions of Latour's apocryphal Portuguese traders that are contradicted. But to contradict oneself is blatantly to use words inconsistently (to "twist their meanings") or to make assertions which are also denied, or which are countered by an opposite and incompatible assertion, without acknowledging or accounting for any discrepancy.

\subsection{Misrecognition}

The concept of misrecognition inverts the notion of recognition, by which we recognize the identity and qualities of our fellows in society (Honneth, 1995; Taylor, 1995). We fail to recognize or respect them. Ricœur (2004: 400) saw the opposites, reconnu - méconnu, as a perpetual threat to communication, through the fundamental asymmetry of the self and the other. However, this also holds out the promise of a Levinasian distinction that could preserve "a suitable [juste] distance", the recognition of the otherness of the other, that is necessary for ethical communication. We keep these tensions in mind as we consider the threat posed by the communicative vices of misrecognition.

In discussing recognition as a communicative virtue, four distinct forms were listed: cognitive, constative, constructive and performative. Here we first consider cognitive, constative and constitutive misrecognition, before moving on to consider dialogic communication and the inversion of performative oaths in curses and blasphemy. While an oath is founded on self-identification, the anonymous performative will be considered as a particular paradox.

Ignorance, Insult and Injury

Cognitive misrecognition involves ignorance of one's partner in communication. This may occur in the second person, when an audience is misrecognized. A speaker may assume an audience has certain characteristics or attitudes which they may not all share. This is a particular risk in addressing people from other cultures, when stereotypes and incorrect generalizations can poison communication. Even more commonly it occurs when an 
audience is not recognized as an audience. I may be speaking to one friend but I am overheard by another. In public life, a politician may address a friendly audience, winning their approval by comments about other groups. This occurs when populist and xenophobic politicians insult Muslims, immigrants or refugees. That they do not care that some remarks are perceived to be insulting by the third party suggests their failure to perceive any common humanity with those groups. It can also genuinely occur in error, as when live microphones broadcast politicians' private comments, private emails are leaked, or recordings from closed meetings come to light.

Intention is also relevant here. Was a speaker intending remarks about a third party to be heard by them? Was offensive stereotyping intended? Or was it merely ignorance? Often the unintended may be just as offensive as the intentional. When a police spokesperson or any other government representative makes unwarranted or offensive assumptions about an audience, ignorance hardly mitigates the damaging impact. When Australian politicians made private jokes about Pacific Islands being inundated (Keany, 2015), even as they resisted entreaties from the leaders of those nations to act on climate change, the fact that they did not know they were being broadcast was no excuse at all.

A particularly pernicious form of misrecognition of third parties is " $\mathrm{dog}$ whistling", which occurs when a politician, for instance, makes coded references in the expectation that they will only be understood by supporters or a specific audience. During the 2016 US presidential campaign Donald Trump, addressing an audience including gun owning supporters of the Second Amendment (that guarantees the right "to bear arms") said, of Hillary Clinton, "If she gets to pick her judges, nothing you can do, folks. Although the Second Amendment people, maybe there is, I don't know." The audience was described by a Trump critic as "people who hate the government and believe they're going to have to take up arms against it. My guess is this is a deliberate dog whistle to that significant number of people" (Smith, 2016). In 2002, the Australian Prime Minister John Howard, who presided over a conservative withdrawal into a mono-ethnic fantasy of the nation, was quoted in an anti-terrorism security booklet distributed to households nationwide: "we must work together to make sure no religion or section of our community is made to feel a scapegoat because of the actions of a small number of fanatics". ${ }^{3}$ Noting the difference between being "made a scapegoat" and Howard's "feel a scapegoat", Watson (2003: 103) decodes this dog whistle:

\footnotetext{
3 Accessed on 21.01.2017, at http://www.austlii.edu.au/au/other/liac/hot_topic/hottopic/2003/2/4. html.
} 
"It might be an unintended slip, of course, but it sends the message - it's all right to blame them, but don't let them hear you." Not only does the dog whistle communicate dangerous or insulting messages, it further insults the intelligence of the target who is expected not to understand.

Misrecognition in public speech inverts the positive constitutive effects of recognition. It does not address the humanity of a (direct or indirect, intended or otherwise) audience, thereby constituting them as partners in discourse. Instead it excludes them, through disrespect, insult or wilful misrecognition. It undermines the esteem in which they are held, by themselves or others. In constitutive discourse each mode of address contributes to making the other who they are. When it diminishes them, it undermines the polity. If communicative action is the foundation of the polity, virtuous communication builds it up; vicious communication tears it down.

\section{The Performative and the Curse: Offense, Blasphemy and Anonymity}

In addition to the constative and constitutive forms of misrecognition, by way of which speakers misunderstand or show disrespect for an audience, there are performative forms which have more direct effects. Performative elements that cause insult and injury can be seen when certain forms of speech are taken for acts. More direct forms of incitement to violence than dog-whistling constitute more direct threats to safety and civility. These distinctions and effects have been central to discussions of "hate speech".

Austin considered authority a central condition of performativity, while Derrida invoked ritual and iteration as lending a similar weight to everybody's actions: the signature was his prime example (Derrida, 1988: 18). Butler (1997) distinguishes between speech and act, noting the role of ritual, iteration and habitus in constituting performatives. Lazzarato draws on Bakhtin and Guattari in order to challenge this distinction between speech and act, asserting that language has no expressiveness independent of enunciation: "[T]he nature of the enunciation is not performative, but dialogic, 'strategic', and event-generating" (Lazzarato, 2014: 181). Insult and injury are not always mediated through language, signification and interpretation. A thoughtless remark or a gratuitous insult can also operate at a visceral and direct level, as action generating action.

Seen in this way, Sarkozy's 2005 reference, in the lead-up to his presidential campaign, to the immigrant youth of the banlieues as "scum", ${ }^{4}$ was

\footnotetext{
4 "Vous en avez assez de cette bande de racailles? On va vous en débarrasser". "Dix ans après. Le 'On va vous débarrasser de la racaille' de Sarkozy", France-Ouest, 16.10.2015. Accessed on 05.09.2016, at http:// www.ouest-france.fr/politique/dix-ans-apres-le-va-vous-debarrasser-de-la-racaille-de-sarkozy-3770713.
} 
not (pace Butler) a performative act of hate speech. Far from operating in the institutionalized and determined space-time of the performative,

it is the space-time of indetermination, unpredictability, the dialogic event, the 'battle-discourse', which seeks to hold sway over others, over their behavior, by restructuring their field of action. (Lazzarato, 2014: 185)

Sarkozy may have hoped that his words would win him votes from the xenophobic Right or goad the Left, or provoke the youth: he could not have known.

In any case, the 'response-reaction' of the 'scum' highlights the dialogic nature of every speech act. ... And [in the following month's riots] this one provoked them all beyond what even their author could have hoped. (ibidem: 186)

While the performative operates in the realm of institutional authority, it remains relevant to aspects of speech and public discourse. Whereas the signature guarantees the efficacy of a document, the oath carries the same weight in spoken enunciations, as was noted in the positive examples by which we are identified and recognized. The vicious inversion of the performative oath is the curse, with its corollary of perjury (Agamben, 2011: $\S 13 \mathrm{ff}$.).

Benveniste (1974: 255) draws a distinction between the constative "to say something", and the performative "to pronounce a name". The difference between expressing a fact or an opinion and pronouncing a name - the name of God or identifying oneself by name - is that between making a statement and a "pure vocal articulation". "This utterance is a performance; 'to swear' consists exactly of the utterance I swear, by which Ego is bound. [...] The utterance is identified with the act itself." (Benveniste, 1971: 229) The very vacuity of the oath, as with any form of the performative, is the source of its power and its mystery. It says nothing, yet it changes the state of the world, by establishing relationships (e.g. marriage or contracts), naming persons or things and invoking consequences for transgression.

Agamben suggests that we may "reread the theory of performatives or 'speech acts', [as] a sort of enigma, as if philosophers and linguists [of the twentieth century] were coming up against a magical stage of language." (Agamben, 2011: §23). Vicious performative utterances make curses of oaths (ibidem: §13), and blasphemies of "euphemies" (Benveniste, 1974: 254). The curse is a presumed performative distinguished by its malevolence. Other forms of misrecognition stem from anonymity. Where an oath expressly requires us to "stand by our word", to swear anonymously is a specific form 
of misrecognition. It involves disavowing our word, that is, misrecognizing our self, and imposing that misrecognition on others.

There has always been the possibility of anonymity in public life. Pasquino, the "source" of graffiti and political commentary in Rome, has stood for anonymity for about two millennia. Yet commentary is not performative and Pasquino never held power. When blasphemies, curses and iconoclasm become anonymous, the authorization of standing by one's own word is betrayed, magnifying the offense. The social order is challenged at the same time that the target is provoked. It is only with the extreme disintegration of the social order "in times of corruption, disintegration and political bankruptcy" that Arendt's anonymous "politically marginal figures" break cover and enter public life (Arendt, 1959: 160). Conversely, we might wonder about the well-being of the polity when the authors of purported performatives hide their identity, and public discourse increasingly hides behind social media avatars in the domain of anonymity. ${ }^{5}$

Throughout this paper we have seen examples of spurious argument, misinformation, disrespect and public threats. While they indicated various degrees of ignorance and malice, all, except unattributed news stories, were sourced to an identifiable public figure. Anonymity is typically found in social media and some other Internet sources, hence the unattributed news. Anonymous curses, in the strict sense of invoking fate, a deity or some other supernatural power to harm someone, are also found on the Internet. Curses are religious injunctions, such as those calling on the faithful to kill Salman Rushdie or, somewhat more obliquely (in the case of the "Second Amendment" faithful), Hilary Clinton. As in these examples, they may be attributable or anonymous. Likewise, blasphemy, in the sense of insulting other people's deities, may be anonymous through the Internet, or attributable to particular publications. We can identify a symmetry between curses and blasphemy, even in contemporary public life. When blasphemy is perceived in the work of authors or cartoonists, a curse commonly follows.

\subsection{Conclusion: Implications for Law and Public Life}

A common legal response to the cycle of blasphemy and curse is to invoke the right to free speech, as was seen in the unedifying spectacle of prominent opponents of liberty and equality parading through Paris with President Hollande, declaring “je suis Charlie” (Todd, 2015: 135). This paper suggests another approach, based on the communicative virtues and vices identified

\footnotetext{
${ }^{5}$ My thanks to Massimo Leone and his class at the University of Turin (7 June, 2016) for pointing out the significance of anonymity.
} 
here. Curses, blasphemy and anonymous performatives have no legitimate place in public discourse. But, doubtful that they should be subject to criminal or civil sanctions, we can explore a different approach to legal discourse.

Adopting a dialogic view of public communication suggests that pursuit of communicative virtues is more important than enforcing rights. As Wolff (1968: 50) pointed out, "It would be madness [...] to suppose that the basic problem for a string quartet is to determine where the rights of the first violinist end and the rights of the cellist begin". Yet, in our contemporary situation, to ask that political and legal deliberation proceed in harmony, andante or largo, is somewhere between a counsel of perfection and an impossible dream.

This paper has tried to build on the strengths and sophistication of discourse theory and communicative ethics, while avoiding their utopian impulse. In recent years, public discourse has sunk to frightening levels of xenophobia and disrespect. The few examples cited here, from Australian prime ministers $(2002,2015)$ and presidential candidates in France (2005) and the United States (2016), have illustrated provocation and insult in twenty-first century political communication. In the absence of any optimistic signs that the level of public debate might be about to improve, it is important to understand the dynamics of vicious communication.

My purpose in analyzing the inverted, vicious forms of the communicative virtues is to understand our imperfect communicative regimes. So, rather than advocating virtue, the key message of this paper can only be to identify vice. By understanding the betrayals of humanity involved in bad faith and misrecognition, in insult and injury, we may be alert to the betrayers. They are the enemies of a legal regime based in communicative competence and harmony. Their methods are guaranteed to destroy a civilized polity. Law must be built on stronger foundations.

In specifically legal settings, this is to be found in resolving disputes, not inflaming them; in mediating between parties, not antagonizing them; in coherence and epistemic responsibility, not in self-contradiction and disregard for truth; in standing by and for one's words, not in anonymity; in understanding the other in his or her otherness, not in condemning their difference. Each of these injunctions can be seen to apply to one or more legal procedures, formal or informal: arguing, legislating, electing or adjudicating.

Yet antagonism, self-contradiction, lying, anonymity and xenophobia are on display in many forms of legal and political discourse. How are we to respond? In the late stages of writing this paper, the infamous leader of the One Nation Party in Australia, Senator Pauline Hanson, made her first 
speech after being re-elected to Parliament. Decrying the "disruption caused by diversity", she then devoted nearly a quarter of her speech to misleading, inaccurate and vicious attacks on Muslims and Islam. She called for a halt to further Muslim immigration and to the building of "mosques or schools", and $a$ ban on the burqa and on Halal certification fees. ${ }^{6}$ The Australian Greens senators stood up and walked out of the chamber. Widely criticized for this move, the party leader, Senator Richard Di Natale, responded:

We chose to walk out of the Senate while Ms Hanson was speaking because we did not want to give any kind of legitimacy to her racist views and to the racist views of others by sitting and listening with the respect usually afforded to parliamentarians during their first speech.[...] And we felt an obligation to stand up for not only Muslims but for the millions of Australians who welcome multiculturalism and an Australia that does not judge you on the colour of your skin or your religious beliefs. (2016)

This is the dilemma confronting those who are committed to communicative ethics. Do we "engage with" those who lie and insult, by listening and responding respectfully? Or do we identify such miscommunication as being beyond the parameters of decent, responsible debate, and therefore refuse engagement? While this analysis has not addressed such choices explicitly, it does offer some guidance. For those concerned with communicative competence and a healthy public sphere, there are ways to debate that allow the parties to engage each other directly. Truth or falsity can be compared, coherence can be expected, contradiction can be questioned, audiences can be addressed and respected. In the absence of these conditions, debate is not possible. Lying, incoherence, self-contradiction, insult and injury fall outside the bounds of public discourse, and cannot be admitted.

To recognize these vices requires an inclusive understanding of the communicative community, which might be a polity, the parties to a dispute, or an international assembly, whether connected by proximity or by telecommunications. An utterance can be judged by the breadth of the speaker's imagined audience. Proper assessment cannot be made by assuming public discourse is addressed to a self-selected private audience. For truly public discourse, the diversity of peoples in the world or within a polity are all part of an inclusive audience.

In any field of legal or political discourse - legislating, electing, adjudicating or arguing - each betrayal is to be named for what it is, before it provokes the next vicious response. Quick communicative intervention

\footnotetext{
${ }^{6}$ Commonwealth of Australia, Parliamentary Debates, Senate, 14 September 2016 (Pauline Hanson).
} 
is needed to identify unconscionable communication if we are to avoid the vicious circle of curse to blasphemy, and blasphemy to curse, until the poison kills the body politic.

Edited by João Paulo Moreira

\section{References}

Agamben, Giorgio (2011), The Sacrament of Language: An Archaeology of the Oath. Stanford: Stanford University Press. Translated by Adam Kotsko [orig. 2008].

Alcoff, Linda Martín (1996), Real Knowing: New Versions of the Coherence Theory. Ithaca: Cornell University Press.

Amaya, Amalia (2008), "Justification, Coherence and Epistemic Responsibility in Legal Fact Finding”, Episteme, 5, 306-319.

Anscombe, G.E.M. (1963), Intention. Oxford: Basil Blackwell.

Appiah, Kwame Anthony (2016), "Mistaken Identities: Creed, Country, Color, Culture", Lecture 4 - Culture, The Reith Lectures. BBC Radio 4. Accessed on 24.11.2016, at http://downloads.bbc.co.uk/radio4/transcripts/2016_reith4_Appiah_Mistaken_ Identities_Culture.pdf.

Arendt, Hannah (1959), The Human Condition. Garden City, NY: Doubleday Anchor. Arendt, Hannah (1982), Lectures on Kant's Political Philosophy. Chicago: University of Chicago Press.

Aristotle (1960), The Rhetoric of Aristotle: An Expanded Translation with Supplementary Examples for Students of Composition and Public Speaking. Englewood Cliffs, NJ: Prentice-Hall. Translated by Lane Cooper.

Aristotle (1995), Politics. Oxford: Oxford University Press. Translated by Ernest Baker. Benhabib, Seyla (1990), "Communicative Ethics and Current Controversies in Practical Philosophy (Afterword)", in Seyla Benhabib; Fred Dallmayr (eds.), The Communicative Ethics Controversy. Cambridge, MA: MIT Press.

Benveniste, Émile (1971), Problems in General Linguistics. Miami: University of Miami Press. Translated by Mary Elizabeth Meek [orig. 1966].

Benveniste, Émile (1974), Problèmes de linguistique générale 2. Paris: Gallimard.

Bourdieu, Pierre (2010), Distinction: A Social Critique of the Judgement of Taste. Abingdon, Oxon: Routledge Classics [orig. 1979].

Brenner, Anastasios (2011), Raison scientifique et valeurs bumaines: essai sur les critères du choix objectif. Paris: Presses Universitaires de France.

Butler, Judith (1997), Excitable Speech: A Politics of the Performative. New York: Routledge.

Cohen, Jean Louise; Arato, Andrew (1992), Civil Society and Political Theory. Cambridge, MA: MIT Press. 
Cooke, Maeve (2013), "Violating Neutrality? Religious Validity Claims and Democratic Legitimacy”, in Craig Calhoun; Eduardo Mendieta; Jonathan VanAntwerpen (eds.), Habermas and Religion. Cambridge, UK: Polity.

Derrida, Jacques (1988), Limited Inc. Evanston, IL: Northwestern University Press. Translated by Samuel Weber and Jeffrey Mehlman.

Di Natale, Richard (2016), "When we Walked Out on Pauline Hanson, we Reached Out to Decent Australians", The Guardian, 16 September. Accessed on 21.01.2017, at http://www.theguardian.com/commentisfree/2016/sep/16/when-we-walked-out-on-pauline-hanson-we-reached-out-to-decent-australians.

Dostal, Robert (2011), “In Gadamer's Neighbourhood”, in Jeff Malpas (ed.), Dialogues with Davidson: Acting, Interpreting, Understanding. Cambridge, MA: MIT Press.

Feldman, Leonard (2008), "Status Injustice: The Role of the State”, in Kevin Olson (ed.), Adding Insult to Injury: Nancy Fraser Debates her Critics. London: Verso.

Fraser, Nancy (1997), “A Rejoinder to Iris Young”, New Left Review, 223, 126-129. Frydman, Benoît (2011), Perelman et les juristes de l'École de Bruxelles. Working Papers du Centre Perelman de Philosophie du Droit. Bruxelles: Université Libre de Bruxelles. Accessed on 22.08.2016, at http://www.philodroit.be/IMG/pdf/ BF_Perelman_et_les_juristes_de_1_ecole_de_bruxelles_def.pdf?lang=fr.

Gadamer, Hans-Georg (1989), Truth and Method. New York: Continuum. Translated by Joel Weinsheimer and Donald G. Marshall [orig. 1960].

Habermas, Jürgen (1990), Moral Consciousness and Communicative Action. Cambridge, MA: MIT Press. Translated by Christian Lenhardt and Shierry Weber Nicholsen [orig. 1983].

Habermas, Jürgen (1991), The Structural Transformation of the Public Sphere: An Inquiry into a Category of Bourgeois Society. Cambridge, MA: MIT Press. Translated by Thomas Burger [orig. 1962].

Habermas, Jürgen (1996), Between Facts and Norms: Contributions to a Discourse Theory of Law and Democracy. Cambridge, UK: Polity Press. Translated by William Rehg [orig. 1992].

Hegel, Georg Wilhelm Friedrich (1967), Hegel's Philosophy of Right. London: Oxford University Press. Translated by Thomas Malcolm Knox [orig. 1821].

Honneth, Axel (1995), The Struggle for Recognition: The Moral Grammar of Social Conflicts. Cambridge, UK: Polity Press. Translated by Joel Anderson [orig. 1992].

Keany, Francis (2015), "Peter Dutton Overheard Joking about Rising Sea Levels in Pacific Island Nations”, ABC News: Australian Broadcasting Corporation, 11 September. Accessed on 31.08.2016, at http://www.abc.net.au/news/2015-09-11/ dutton-overheard-joking-about-sea-levels-in-pacific-islands/6768324.

Kennedy, Duncan (1997), Critique of Adjudication (Fin de Siècle). Cambridge, MA: Harvard University Press. 
Latour, Bruno (1996), Petite réflexion sur le culte moderne des dieux faitiches. Paris: Synthélabo.

Lazzarato, Maurizio (2014), Signs and Machines: Capitalism and the Production of Subjectivity. Los Angeles: Semiotext(e). Translated by Joshua David Jordan.

Levinas, Emmanuel (1989), "Ethics as First Philosophy", in Séan Hand (ed.), The Levinas Reader. Oxford: Basil Blackwell. Translated by Seán Hand and Michael Temple. [orig. 1984].

McDowell, John (1996), Mind and World. Cambridge, MA: Harvard University Press. Perelman, Chaï (1980), Justice, Law, and Argument. Essays on Moral and Legal Reasoning.

Dordrecht: D. Reidel Publishing Company. Translated by William Kluback.

Ricœur, Paul (2004), Parcours de la reconnaissance: trois études. Paris: Gallimard.

Ryan, Alan (1996), "Professional Liars”, Social Research, 63, 619-641.

Santos, Boaventura de Sousa (1995), Toward a New Common Sense: Law, Science and Politics in the Paradigmatic Transition. New York: Routledge.

Smith, David (2016), "Donald Trump Hints at Assassination of Hillary Clinton by Gun Rights Supporters", The Guardian, 9 August. Accessed on 18.08.2016, at http://www.theguardian.com/us-news/2016/aug/09/trump-gun-owners-clinton-judges-second-amendment.

Taylor, Charles (1995), Philosophical Arguments. Cambridge, MA: Harvard University Press.

Teubner, Gunther (1989), "How the Law Thinks: Toward a Constructivist Epistemology of Law", Law and Society Review, 23, 727-757.

Thielman, Sam (2016a), "Facebook News Selection is in Hands of Editors not Algorithms, Documents Show", The Guardian, 13 May. Accessed on 30.08.2016, at http://www.theguardian.com/technology/2016/may/12/facebook-trending-news-leaked-documents-editor-guidelines.

Thielman, Sam (2016b), "Facebook Fires Trending Team, and Algorithm without Humans Goes Crazy", The Guardian, 30 August. Accessed on 30.08.2016, at http://www.theguardian.com/technology/2016/aug/29/facebook-fires-trending-topics-team-algorithm.

Todd, Emmanuel (2015), Qui est Charlie? Sociologie d'une crise religieuse. Paris: Editions du Seuil.

Toulmin, Stephen (1964), The Uses of Argument. Cambridge, UK: Cambridge University Press.

Varga, Csaba (1985), The Place of Law in Lukács’ World Concept. Budapest: Akadémiai Kiadó. Translated by Judit Petrányi and Sándor Eszenyi.

Watson, Don (2003), Death Sentence: The Decay of Public Language. Sydney: Knopf. Wolff, Robert Paul (1968), The Poverty of Liberalism. Boston: Beacon Press.

Young, Iris Marion (1987), "Impartiality and the Civic Public", in Seyla Benhabib; Druscilla Cornell (eds.), Feminism as Critique: On the Politics of Gender. Minneapolis: University of Minnesota Press. 
Young, Iris Marion (1990), Justice and the Politics of Difference. Princeton, NJ: Princeton University Press.

Young, Iris Marion (1997), “Unruly Categories: A Critique of Nancy Fraser's Dual Systems Theory”, New Left Review, 222, 147-160.

Received on 23.09.2016

Accepted for publication on 01.02 .2017

\section{Richard Mohr}

Social Research Policy and Planning Pty Ltd

PO Box 202 Dulwich Hill, NSW 2203, Australia

Contact: rmohr@srpp.com.au

\section{Direito e argumento por um mundo culturalmente diversificado: como não comunicar}

O presente artigo faz uma revisão do papel do discurso no direito e na vida pública e identifica ameaças que surgem na política, resultantes de formas de comunicação maliciosas. Para além do papel que assume na argumentação legal, a comunicação é fundamental para o debate público na criação de leis e políticas, constituindo ainda o tecido social e político através da utilização de formas de tratamento e de reconhecimento dos outros. Este argumento baseia-se em aspetos da teoria do discurso, da teoria feminista e de outras críticas que sugerem que se aplica a uma comunidade restrita de discurso, excluindo outras culturas. Assume uma perspetiva alargada de participantes no debate público, que necessariamente ultrapassa fronteiras nacionais e culturais. Uma comunicação responsável exige que se argumente de boa-fé, com verdade e coerência, e que se reconheçam os intervenientes na discussão, tanto por aquilo que são, como pelo

\section{Droit et argument pour un monde culturellement diversifié: comment ne pas communiquer}

Cet article passe en revue le rôle du discours dans le droit et dans la vie publique et identifie des menaces qui apparaissent en politique à partir de formes de communication malveillantes. En plus de son rôle dans l'argument juridique, la communication est fondamentale pour le débat public dans la formation des lois et des politiques, et elle constitue le tissu social et politique à travers l'utilisation de formes d'adresse et de reconnaissance d'autrui. Cet argument s'appuie sur des aspects de la théorie du discours, de la théorie féministe et d'autres critiques suggérant qu'il s'applique à une étroite communauté de discours, ce qui exclut d'autres cultures. Il assume une vision élargie des participants au débat public, qui traverse nécessairement les frontières nationales et culturelles. La communication responsable exige de nous une discussion de bonne foi, véridique et cohérente, et que nous reconnaissions nos partenaires en discussion, tant pour 
papel que detêm numa comunidade partilhada. $\mathrm{O}$ artigo argumenta que o discurso público desceu a níveis perigosos neste século, citando exemplos de má-fé, provocação e insulto por parte de primeiros-ministros australianos $(2002,2015)$ e candidatos presidenciais na França (2005) e nos Estados Unidos (2016). Conclui defendendo que a mentira, a incoerência, a contradição, o insulto e a injúria se situam fora dos limites do discurso público. É necessária uma intervenção rápida ao nível da comunicação, que identifique cada uma destas formas de comunicação maliciosa como uma traição do público cívico, antes que se desencadeie a próxima reação maliciosa.

Palavras-chave: comunicação maliciosa; direito; diversidade cultural; epistemologia; retórica; teoria do discurso. ce qu'ils sont, que pour leur place dans une communauté partagée. L'article fait valoir que le discours public a atteint des niveaux dangereux au cours du siècle présent, en citant des exemples de mauvaise foi, de provocation et d'insulte de la part de premiers ministres australiens $(2002,2015)$ et de candidats présidentiels en France (2005) et aux États-Unis (2016). Il conclut que le mensonge, l'incohérence, l'auto-contradiction, l'insulte et la blessure sont hors limites du discours public. Une intervention communicative rapide est nécessaire pour identifier chacune de ces formes de communication malveillante comme une trahison du public civique, avant qu'elle ne provoque la prochaine réponse vicieuse. Mots-clés: communication malveillante; diversité culturelle; droit; épistémologie; rhétorique; théorie du discours. 